\title{
Favorability potential for IOCG type deposits in the Riacho do Pontal Belt: new insights for identifying prospects of IOCG-type deposits in NE Brazil
}

\author{
Sérgio Roberto Bacelar Hühnn ${ }^{1,2 *}$ (D), Adalene Moreira Silva ${ }^{2}$
}

\begin{abstract}
Archean iron oxide-copper-gold (IOCG) deposits have been systematically described in the world class Carajás IOCG district, Amazonian region of Brazil. More recently, several Neoproterozoic (ca 1.13 to $0.96 \mathrm{Ga}$ ) IOCG deposits have been identified in the Riacho do Pontal mobile belt situated in the Borborema Province on the northern border of the Säo Francisco Craton. In these Neoproterozoic deposits, several copper occurrences have been mapped along shear zones. The primary hydrothermal mineral associations resulted in sodic, calcic-potassic and potassic-ferric alteration. The copper grades of the main prospects range between 0.5 and $0.8 \mathrm{wt} \%$ with an average of $-0.7 \mathrm{wt} \%$. This study uses a fuzzy logic approach to create regional to district scale predictive exploration models. Specifically, multi-parameter geologic, geochemical, remote sensing, and airborne geophysical data incorporated into regional and local models predict known copper mineralization and, importantly, highlight prospective areas for new IOCG targets in the Borborema Province. At district scale, multiple higher resolution geological, soil geochemical, and airborne geophysical data that cover the Riacho do Pontal Belt, were analyzed. A drilling exploration program implemented on target RIA4 validated these model results. Drill hole RIA4-DHOOO1 crosscuts a mineralized zone with $32 \mathrm{~m}$ of $1.15 \mathrm{wt} \%$ copper.
\end{abstract}

KEYWORDS: copper; iron oxide-copper-gold; shear zones; hydrothermal alteration; fuzzy logic; Borborema Province.

\section{INTRODUCTION}

Iron Oxide-Copper-Gold (IOCG) deposits include a wide spectrum of copper deposits types showing high content of magnetite and/or hematite with low titanium content (Hitzman et al. 1992). Their age of formation ranges from Archean to Phanerozoic. The mineralizations are frequently associated with intrusive magmatic bodies (Hitzman 2000, Pollard 2001, Williams et al. 2005, Williams 2010, Xavier et al. 2008, Xavier et al. 2010) and are commonly found in breccias, veins, stockworks or lenses with polymetallic enrichments ( $\mathrm{Cu}, \mathrm{Au}, \mathrm{Ag}, \mathrm{P}, \mathrm{U}$ and REE) that are tectonically-controlled along shear zones. Interest in IOCG deposits was boosted after the discovery in 1975 of the Olympic Dam deposit and the consolidation of the mineral potential of the Gawler range region in South Australia. In the late 1990s, a reinterpretation of the typology of Archean copper deposits of the Carajás Mineral Province such as Salobo, Sossego, Cristalino and Igarapé Bahia-Alemão deposits (Hühn \& Nascimento 1997, Lindenmayer 2003, Tallarico et al. 2005, Monteiro et al. 2008, Grainger et al. 2008, Groves et al. 2010, Juliani et al. 2016), which show many similarities with other IOCG deposits (Hitzman et al. 1992, Hitzman 2000), led to a boom in exploratory activity in Brazil.

The significance of the Neoproterozoic copper deposits of the Borborema Province as potential IOCG deposits was first emphasized by Maas et al. (2003), Machado (2006) and Hühn et al. (2011). These authors interpreted the geological and geochemical signature of copper occurrences associated with quartz-hematite breccias in the region of Mandacaru, São Juliāo, Fronteiras and Pio IX, Campos Sales and Aurora as a succession of IOCG mineralizations, formed as a response of intensive hydrothermal alteration

1Vale S.A. - Santa Luzia (MG), Brazil. E-mail: sergio.bacelar@vale.com

${ }^{2}$ Laboratory of Applied Geophysics, Institute of Geosciences, Universidade de Brasília - Brasília (DF), Brazil. E-mail: adalene@unb.br *Corresponding author.

Manuscript ID: 20180029. Received on: 03/13/2018. Approved on: 08/22/2018. 
in km-scale shear zones (Hühn et al. 2014). The most important deposit is the Riacho Seco Copper Project (5 Mt ( $0.8 \% \mathrm{Cu}$ ), which is part of the Riacho do Pontal Fold Belt (RPFB) and was discovered by Companhia Baiana de Pesquisa Mineral (CBPM) in 1974. The mineral potential of the RPFB is still unknown due to a lack of systematic exploration activities and elaborate academic studies.

The main objective of this paper is to integrate an extensive geophysical, geological and geochemical dataset using a fuzzy modeling approach in order to build a robust and rigorous protocol adapted for exploration of the Riacho do Pontal IOCG district. The data integration revealed new high-quality targets of potential interest for mining exploration. The economic interest of one of these targets was validated by a drill core campaign.

\section{GEOLOGICAL SETTING AND COPPER MINERALIZATION}

The RPFB is part of the Borborema Province located in the northern part of the Sáo Francisco Craton (Brito-Neves 1975, 1983, Almeida et al. 1976) in Northeast Brazil (Fig. 1). It represents Meso to Neoproterozoic sequences that were deformed during the Brazilian orogeny (Fuck et al. 1993). The Borborema Province is limited to the south by the São Francisco Craton, to the west by the Parnaíba Basin and to the north and east by the sedimentary basins of the coastal margin (Fig. 1).

Using gravimetric and magnetic data, Oliveira \& Medeiros (2000) subdivided the Borborema Province into five major tectonic blocks. They are:

- Médio Coreaú;

- Ceará (or Cearense);

- Rio Grande do Norte;

the Transverse or Central zone;

the South or External zone (Fig. 1).

On the basis of geological and structural studies, Jardim de Sá et al. (1992) proposed that the Borborema Province is composed of different domains that experienced distinct tectono-metamorphic evolutions, i.e., a gneissic-migmatitic basement and different supracrustal units showing different tectonic-stratigraphic evolution. Santos (1996), using a lithostratigraphic approach, identified a variety of sedimentary terrains, which were grouped into three main belts defined as the northern, transverse and southern (external) belts (e.g., Santos et al. 1997, Jardim de Sá 1994, Brito-Neves et al. 2000, 2005).
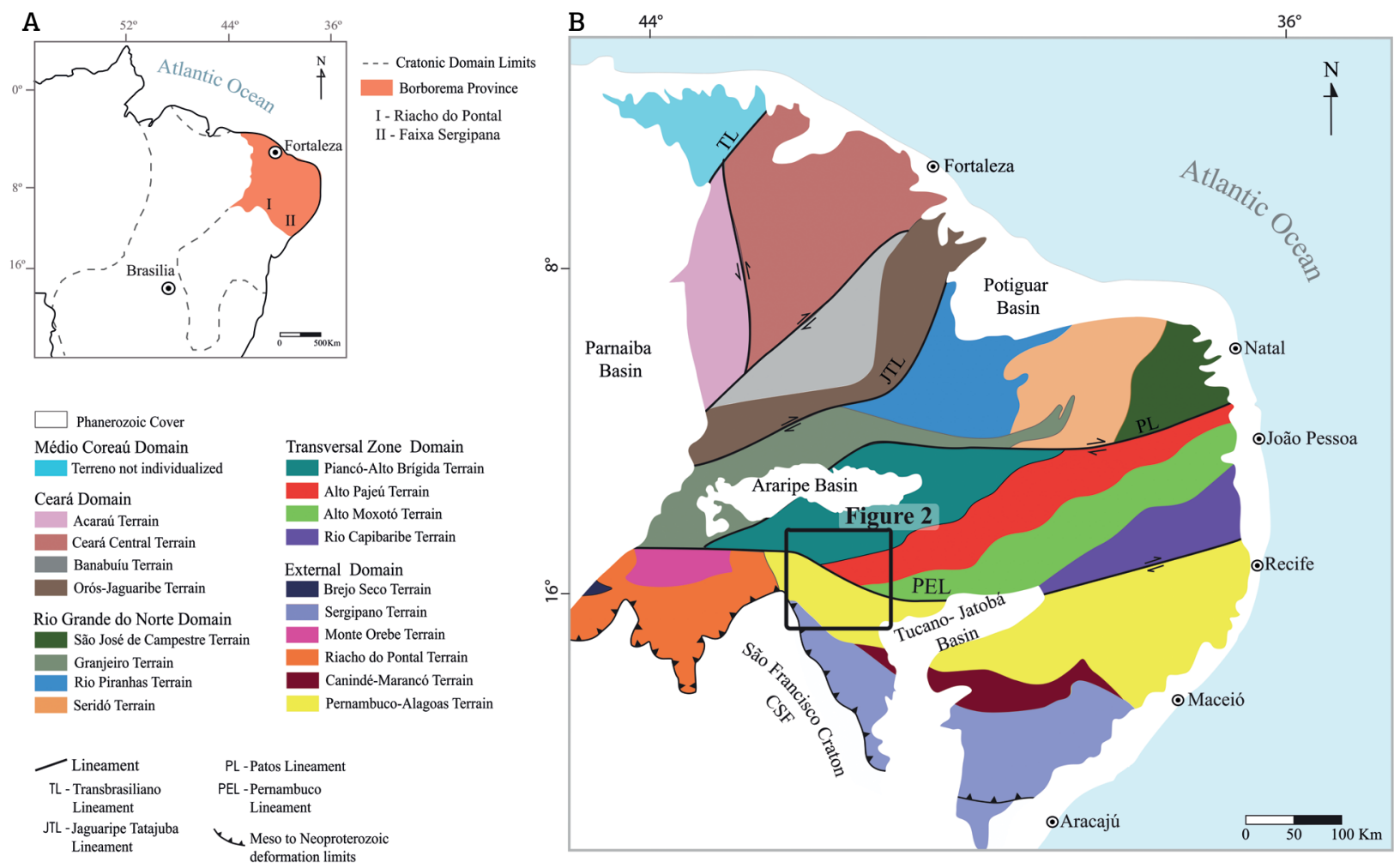

Figure 1. (A) Tectonic positioning of the regional geology of Northeast Brazil in relation to Craton São Francisco and Borborema Province; (B) simplified tectonic map of São Francisco Craton and regional geological map of Borborema Province (BP) showing the Riacho do Pontal Belt (Gomes 1998, Oliveira \& Medeiros 2000). 
Detrital zircons collected in the meta-sedimentary rocks forming the Borborema Province show a range of $\mathrm{U}-\mathrm{Pb}$ ages between 980 and $1199 \mathrm{Ma}$, which were interpreted to reflect a maximum depositional age related to Brazilian orogeny (Oliveira et al. 2006). Granite zircon U-Pb ages show the occurrence of two main types of intrusive bodies: pre-collisional granitoids such as the $628 \pm 12 \mathrm{Ma}$ old Camará tonalite and 571 to $584 \mathrm{Ma}$ old syn-collisional granites (e.g., Angico and Pedra Furada granites; Bueno et al. 2009).

The limit of the Borborema Province with the northern border of the São Francisco Craton (Fig. 1) has been mapped by thrust shear zones and is interpreted as a Brazilian collisional zone developed during a convergence episode of Neo to Mesoproterozoic age (Alkmim et al. 1993).

Exploration activities conducted during the 1970s, which were focused on volcanogenic massive sulfide mineralization (Franklin et al. 1981, Lindenmayer 1981), led to the discovery of the Caraíba mine (24 MT@ 1,8 \% Cu). The Caraíba mine occurs on the north portion of São Francisco Craton and is part of the Vale do Curaçá district (Fig. 1B). It has been described as having a magmatic origin in several studies (Delgado \& Sousa 1975, Lindenmayer 1981, Oliveira \& Tarney 1995). According to Garcia (2013), the formation of the Vale do Curaçá district is characterized by a multiphase evolutionary history, which includes:

a primary magmatic mineralization stage at ca. $2.6 \mathrm{Ga}$;

- development of the Itabuna-Salvador-Curaçá metamorphic zone at ca. $2.08 \mathrm{Ga}$;

remobilization during orogenic collapse and emplacement of an IOCG system at ca. 2.04 Ga, associated with mineralization epigenetics (Teixeira et al. 2010, Fraguas 2012, Garcia 2013);

uplift of the orogen and late stage metasomatism at ca. $1.92 \mathrm{Ga}$.

\section{The Riacho do Pontal Prospect}

According to Bueno et al. (2009) and Hühn et al. (2014), the central portion of the Riacho do Pontal prospect is mainly composed by gneisses and tonalites of the Sobradinho Remanso Complex (Fig. 2). This geological unit lays in contact to the South with dolomitic marble and subordinated quartzites of the Macururé Group and is intruded by syn-collisional granites towards the south. The rocks of the Macururé Group are thrusted over the São Francisco Craton.

Several main shear zones oriented NW-SE occur cut across by late NE-SW faults. The major ones include Riacho Seco, Macururé, North and Central shear zones. Riacho Seco (RSSZ) and Macururé (MSZ) correspond to thrust faults, while the North (NSZ) and Central (CSZ) are clockwise strike-slip shear zones.

\section{GEOPHYSICAL, GEOCHEMICAL AND GEOLOGICAL CONSTRAINTS}

\section{Airborne geophysical survey}

Airborne magnetic and gamma-ray survey was flown in 2005 over the Pernambuco-Piauí area using 500-m-spaced north-south-oriented flight lines, with tie lines flown every $250 \mathrm{~m}$ at a nominal altitude of $100 \mathrm{~m}$ above ground. The Pernambuco-Piauí survey consisted of $104,120 \mathrm{~km}$ of high-resolution magnetic gamaespectrometric profiles oriented N-S. Details of the data acquisition protocol, the aircraft used, and the geophysical sensors utilized can be found at the Brazil Geological Survey (CPRM 2006).

The flight line magnetic data were corrected for the International Geomagnetic Reference Field (IGRF) and interpolated onto a $125 \mathrm{~m}$ grid using a bidirectional gridding method. Using the appropriate algorithms to preserve data fidelity at the original sample location, this method enhances magnetic features perpendicular to the flight line direction. The algorithm was based on linear interpolation along the direction of the flight lines and on Akima spline interpolation perpendicular to the flight lines. Microleveling and decorrugation techniques were also applied to the data. The magnetic anomaly data were reduced-to-the-magnetic-north pole (RTP) assuming an inclination of $-20^{\circ}$ and a declination of $-22.31^{\circ}$. The results were compared with the calculation of the amplitude of the analytic signal (ASA). The ASA is of central interest to locate the spatial distribution of magnetic sources (Naghibian 1972, Li 2006, Roest et al. 1992) and evaluate the best solution in accordance with geological data and interpretation.

In the Riacho do Pontal prospect, a total of 18 copper occurrences located on low magnetic anomalies lining shear zones was identified using this protocol (Figs. 3, 4, 5 and 6). These shear zones show intense hydrothermal alteration overprint. To identify the different rock types affected by these hydrothermal processes, ratios between gamma-spectrometric channels were used (Ostrovskiy 1975, Pires 1985). Specifically, the parameter $\mathrm{F}=\mathrm{K} x$ (eU/eTh) (Efimov 1978), which establishes to co-evolution of the abundance of $\mathrm{K}$ and the eU/eTh ratio, has been widely used. Additionally, because of the relative less mobile character of Th, Saunders et al. (1987) and Pires (1985) used the normalization of $\mathrm{K}$ and $\mathrm{U}$ by $\mathrm{Th}$ to evaluate $\mathrm{K}$ anomalies along shear zones.

According to Oliveira (2008), it is possible to observe, on a regional scale, that the supracrustal sequence of the Riacho do Pontal and Sergipana bands were placed aloctone with displacements of the order of 30 to $60 \mathrm{~km}$ (Jardim de Sá et al. 1992). Oliveira (2008) showed that the area of the 
Riacho do Pontal Fold Belt has a regional positive gravimetric anomaly with a wavelength of $200 \mathrm{~km}$ and an amplitude of $60 \mathrm{mgal}$. The region has an aeromagnetic pattern characterized by dominant shallow sources defined by positive E-W linear axis with amplitudes less than $100 \mathrm{nT}$ and short wavelengths $(10 \mathrm{~km})$. The anomaly is interpreted as the result of a crustal shortening related to a neoproterozoic collisional process (Fig. 3).

\section{Stream sediment and soil geochemistry}

The stream and soil sediments geochemical data were used in the data integration to identify new exploration targets. The geochemical data available for the Riacho do Pontal project include major and trace element compositions of both stream and soil sediments. Stream sediments were collected in active river beds and analyzed by the Brazil Geological Survey. A total of 194 stream sediments was

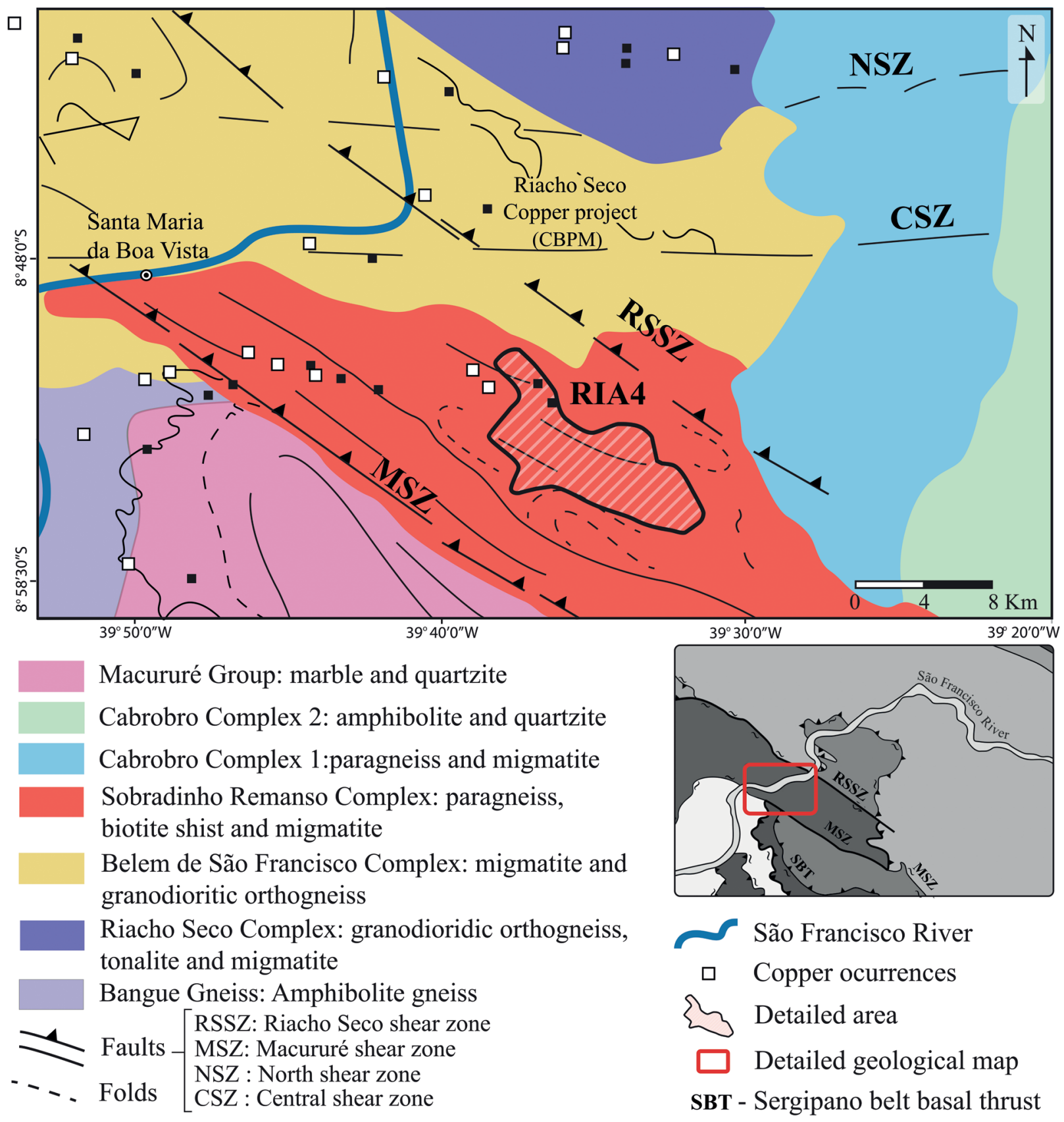

Figure 2. Simplified local geological map of the Riacho do Pontal prospect (after Bueno et al. 2009). The red dashed polygon Ria4 is approached in validation of the potential targets. 


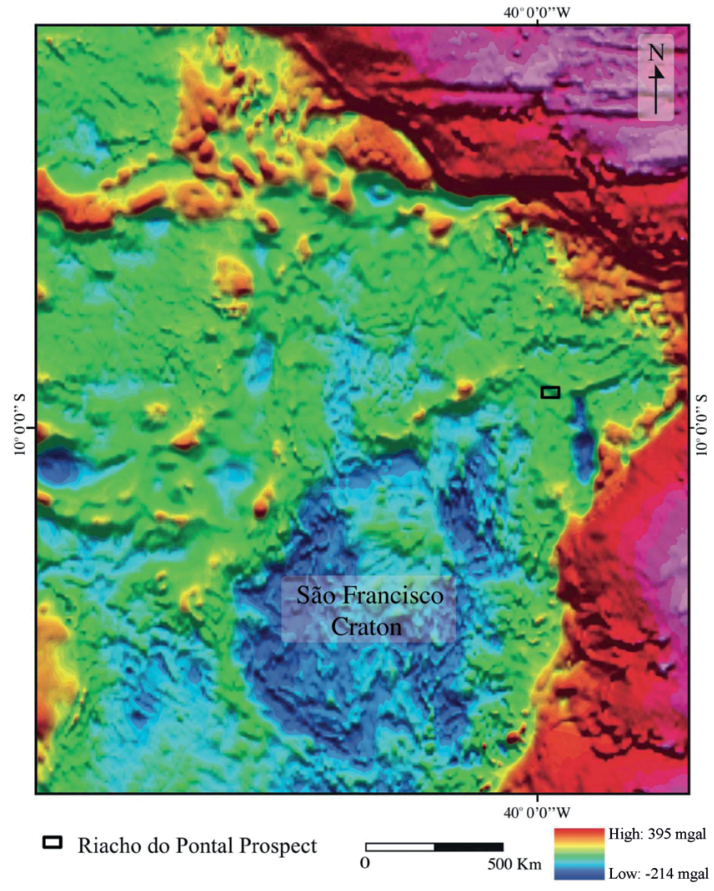

Figure 3. Regional Bouguer anomaly map showing the signature of the São Francisco Craton and surrounding Brazilian fold belt. The black polygon outline the Riacho do Pontal prospect studied here. obtained over an area of $1816 \mathrm{~km}^{2}$. Each sample represents the sum of different fractions of sediments collected over an area of about 5.000 to $10.000 \mathrm{~m}^{2}$. The samples were dried at $60^{\circ} \mathrm{C}$, sieved to a fraction of $<80$ mesh, and sprayed to a fraction of $<150$ mesh. The samples were dissolved using aqua regia $\left(3: 1 \mathrm{HCl}: \mathrm{HNO}_{3}\right)$. The chemical analyses were performed using a combination of ICP-AES and ICP-MS.

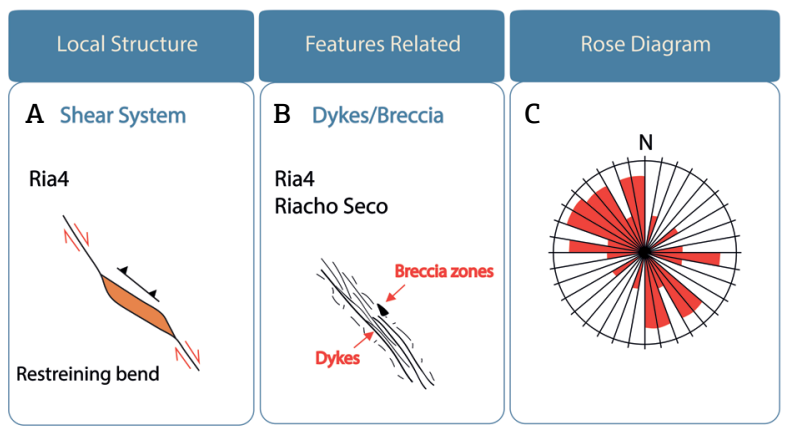

Figure 5. Map showing the local geologic structures at Riacho do Pontal prospect; (A) features related to copper occurrences at the Riacho do Pontal and Riacho Seco prospect; (B, C) Rose diagram showing major NW and NE shears.

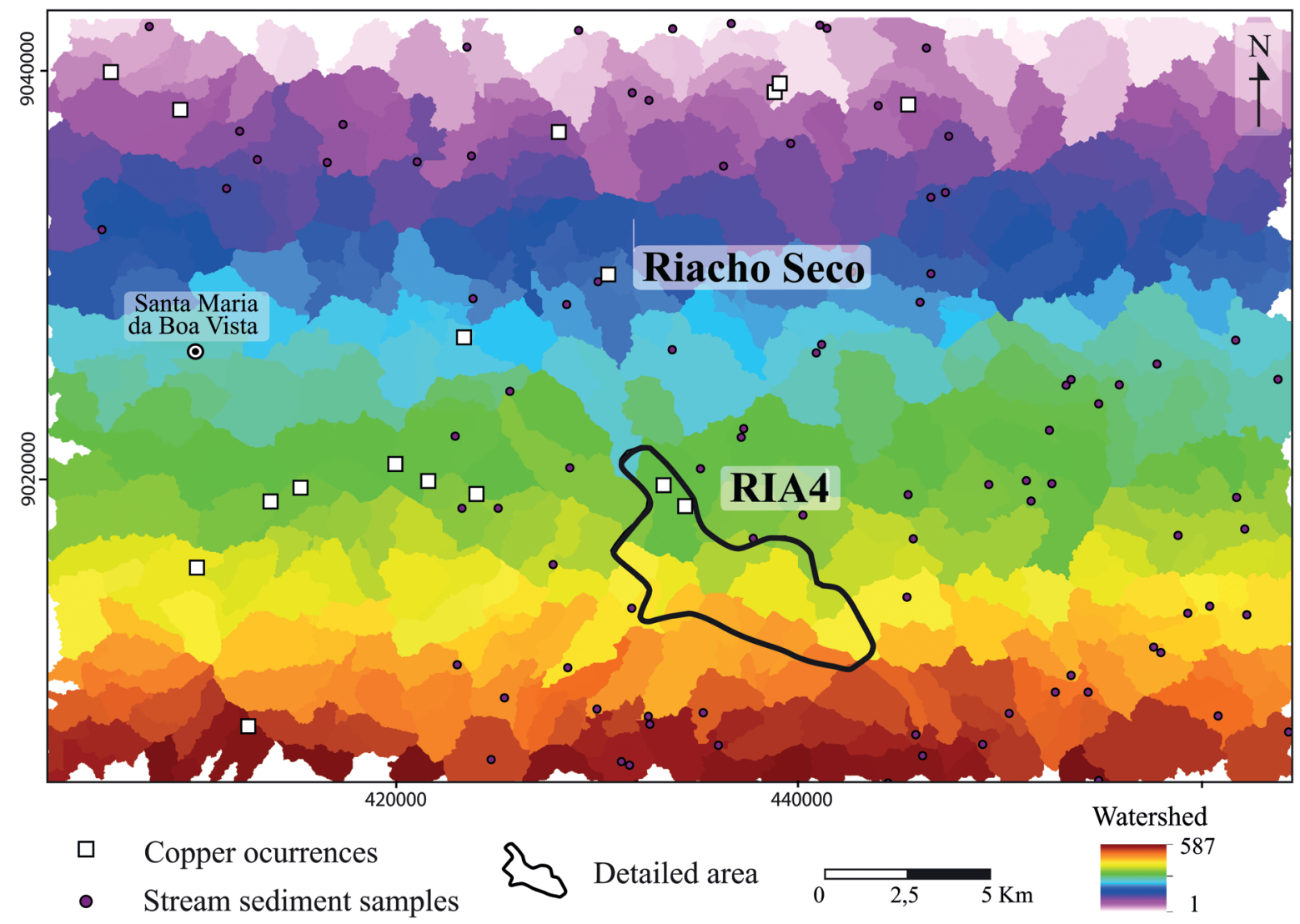

Figure 4. Stream sediment samples and catchment basins processing used at the Riacho do Pontal prospect. The black polygon RIA4 is approached in validation of the potential targets. 
Using a digital terrain model (DTM), sediment geochemical data were processed at a sub-basin scale according to the following protocol (Buarque 2007, Fig. 4):

- extraction of drainage effect without generating depressions;

generation of a matrix file with the direction of flow for each cell;

generation of a cumulative flow matrix file for each cell;

- extraction of drainage network;

conversion to vector file;

delimitation of watershed areas, with the definition of values corresponding to the direction of flow in the basin, for each drainage section;

generation of the map of sub-basins (Carranza \& Hale 1997).

The samples were interpolated in a grid using barriers for each catchment basin and a minimum curvature spline technique. Figure 4 shows the geochemical stream sediment samples and catchment basin maps that were generated.
Stream sediment grid data were interpreted and integrated with geophysical and geological data.

Soils are poorly developed in the Riacho do Pontal prospect as weathering is limited in this arid climate with no apparent laterite profile. The collected samples are mainly composed of siltstones and sandstones containing abundant angular fragments, hence arguing for limited transport. These sediments may therefore reflect the nature of the immediately underlying host rock. However, due to high grade metamorphism and, potentially, hydrothermal alteration, the protoliths are seldom recognizable. A total of 1.494 soil samples was collected along NW-SE trending line profiles up to $1.6 \mathrm{~km}$ in length, which were obtained throughout the area labeled RIA4 in Figure 3. Samples were analysed by AR/ICP-OES (ME-ICP41) for 33 elements and by FA-ICP (PGM-ICP23) for Au, Pt and $\mathrm{Pd}$. The chemical soil data were interpolated in a grid using kriging data processing.

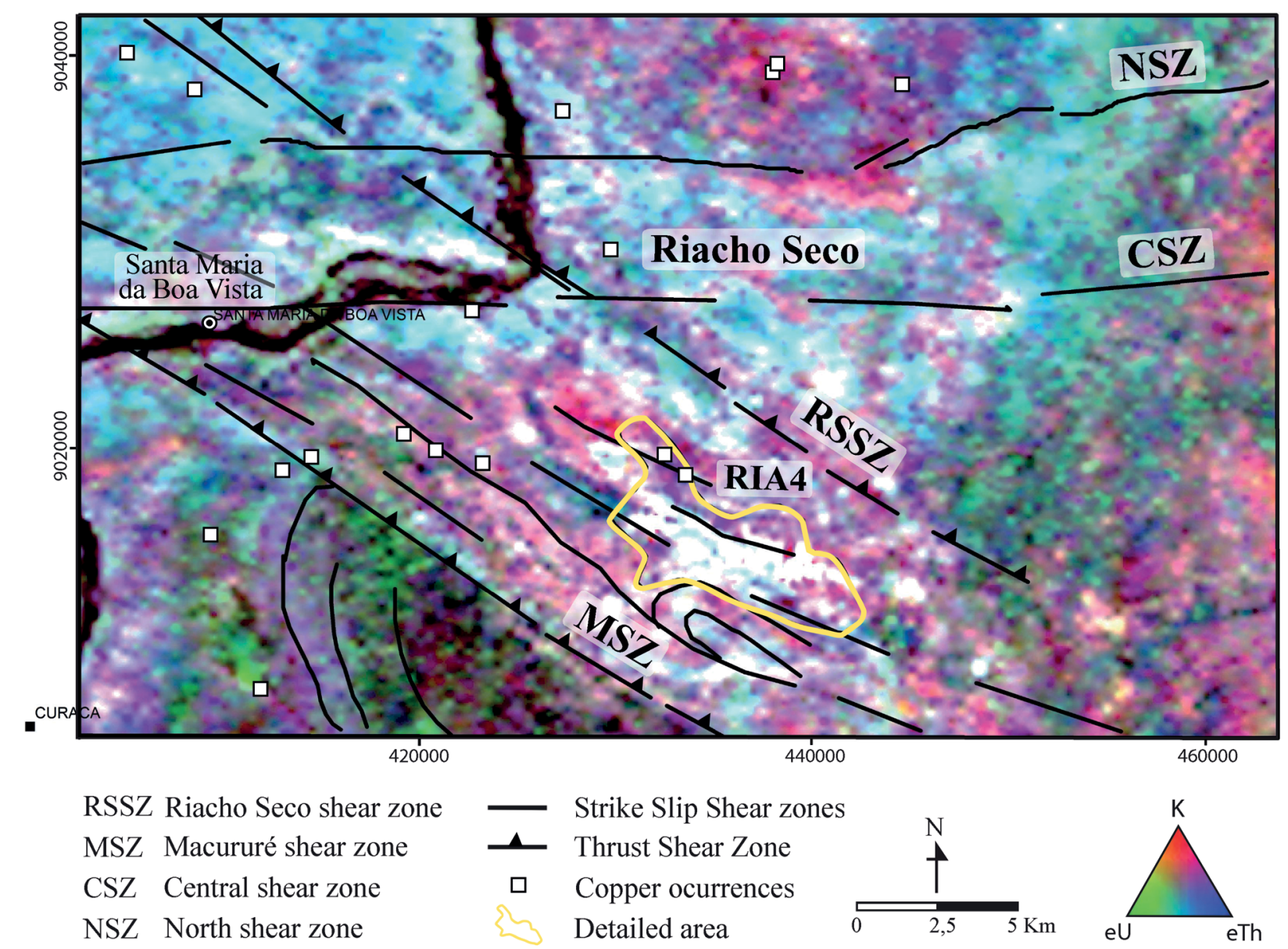

Figure 6. Ternary image of the Riacho do Pontal prospect area showing the distribution of potassium (K, red), thorium (Th, blue) and uranium (U, green). The yellow polygon RIA4 is approached in validation of the potential targets. 


\section{Geological and drill core geochemical data}

The geological map of the Riacho do Pontal prospect was constructed using regional maps available at CPRM and data obtained from Vale exploration (Vale S.A. 2009). The structural interpretation was performed using Aster images and airborne magnetic derivative products. In addition, four drill holes representing 1295,30 m of cores were performed during the exploration campaign. Among these, only three holes were analysed for their major and trace element compositions. The fourth drill hole RCB-RIA4-DH00001 was analysed down to $63 \mathrm{~m}$ depth only. All samples were digested by Agua Regia technique and analysed by ICP-OES (ME-ICP41) for 33 elements and FA/ICP-OES for Au (Shriver 2009).

\section{RESULTS}

\section{Geological and structural data}

The Riacho do Pontal prospect has a strong NW-oriented structural fabric that is represented by major shear zones. The mainly units of the Riacho do Pontal prospect are characterized by rocks composed of gneiss and migmatites. The metasedimentary cover is composed of quartzite and schists. Petrographic studies using Energy Dispersive X-ray Spectrometry coupled with Scanning Electron Microscope allowed the characterization of hydrothermal mineral signature (Hühn et al. 2014). Hydrothermal alteration led to a pervasive calcic-potassic and calcic-ferric overprint of the host gneisses and migmatites. Early stage sodic hydrothermal is distal in relation with areas with calcic-potassic and potassic-ferric alteration with higher strain rate. The hydrothermal alteration process led to a replacement of metamorphic minerals of banded gneiss by hydrothermal assemblages (Tab. 1).

The Riacho do Pontal prospect has a strong NW-SE oriented structural fabric that is represented by shear zones identified in Figure 4. Locally, strongly mylonitized rocks along shear zones define an L-S tectonite fabric. Ore zones are strongly controlled by restraining bends of shear and late breccia zones along the bends (Fig. 5). Secondary ore zones are sub parallel to these major lineaments. Late faults oriented NE-SW representing a late stage of brittle extensional deformation are frequent in the region.

\section{Geophysical data}

Gamma ray spectrometric data have been very useful for mapping geological units and hydrothermal zones of Riacho do Pontal prospect (Hühn et al. 2014). The ternary image of Figure 6 (RGB colors) represents a compositional map of $\mathrm{U}$, Th and K. Different subdomains can be recognized. In the central portion of the area, where orthogneiss rocks of the Sobradinho Remanso Complex show outcrops, intense potassic hydrothermal alteration

Table 1. Hydrothermal alteration and mineralogical assemblages related to copper mineralization zones in the Riacho do Pontal prospect.

\begin{tabular}{|c|c|c|c|}
\hline Minerals & Distal (Sodic) & Transitional (Calcic-Potassic) & Proximal (Potassic-Ferric) \\
\hline Plagioclase & $-\ldots-\ldots$ & $-\ldots-\ldots-\ldots$ & \\
\hline Chlorite &.----- & $-\ldots$ & \\
\hline Ilmenite & -------- & ----------- & \\
\hline Albite & 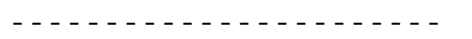 & & \\
\hline Amphibole & & $\ldots \ldots-\ldots$ & \\
\hline Biotite & & ---------- & $-\ldots-\ldots-\ldots-\ldots$ \\
\hline Garnet & $---\ldots--$ & 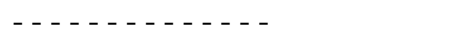 & \\
\hline Quartz & & ---- & --- \\
\hline Apatite & & & 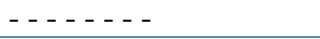 \\
\hline Hematite & & & $-\ldots-\ldots$ \\
\hline Pyrite & & & ---- \\
\hline Chalcocite & & & ---- \\
\hline Chalcopyrite & & & $\ldots$ \\
\hline
\end{tabular}


can be recognized in the RSSZ and MSZ. This potassic alteration occurs locally associated with strong enrichments in hematite and/or magnetite. Specifically, large magnetite bodies were identified along the NSZ, which cut across the gneisses of the Complexo Belém do São Francisco. The white areas in the central part of the ternary map along the RSSZ, the MSZ and the CSZ correspond to intense siliceous alteration zones.

Figure 6 shows a flowchart that summarizes the enhancement techniques applied to magnetic data of the studied area. Results generated from the magnetic data include:

a map of the total magnetic intensity (TMI);

the first order derivatives along two horizontal components (Dx, Dy) and one vertical component (DZ);

the 3D ASA calculated from the TMI (Roest et al. 1992).

These data were used to delineate the boundaries of the sources and assist with the magnetic and structural interpretations of the studied area (Fig. 5), including the amplitude of the analytical signal and the "worm" method (WM, see below; Archibald et al. 1999).

Multi-scale Edge Mapping (MED or Worm-WM) is a process of highlight edges in potential field data (Archibald et al. 1999). MED involves upward continuation processing to separate the potential field data into shallow high frequencies associated with short wavelength responses, in contrast with deeper low frequencies related to long wavelength responses. The MED processing seeks to decrease the ambiguity in potential field interpretation and provide useful information about the general shape and relative depth of edges, such as faults and geological contacts (Archibald et al. 1999). In the studied area, the worm linear features represent irregularities of the potential field data, corresponding to major geological contacts and shear zones (Figs. 7 and 8).

With the exception of the RSSZ, Figure 7 shows that the major shear zones mapped on the surface which show a dominant NW trend dipping 50 degrees to the NE, overlap relatively well with the WM (MED) structures. In addition, the two main strike-slip shear zones (CSZ and NSZ) displaying a subvertical EW trendare strongly underlined by the WM structures, which indicates that they represent deeply rooted features. The absence of a clear overlap with the RSSZ argues for a shallow structure (Fig. 8). Between the MSZ and RSSZ structures, second order thrust structures are also quite concordant with the WM data. Note that he RIa4 target is bounded to the south by a secondary NW-SE trending shear zone (Fig. 8).

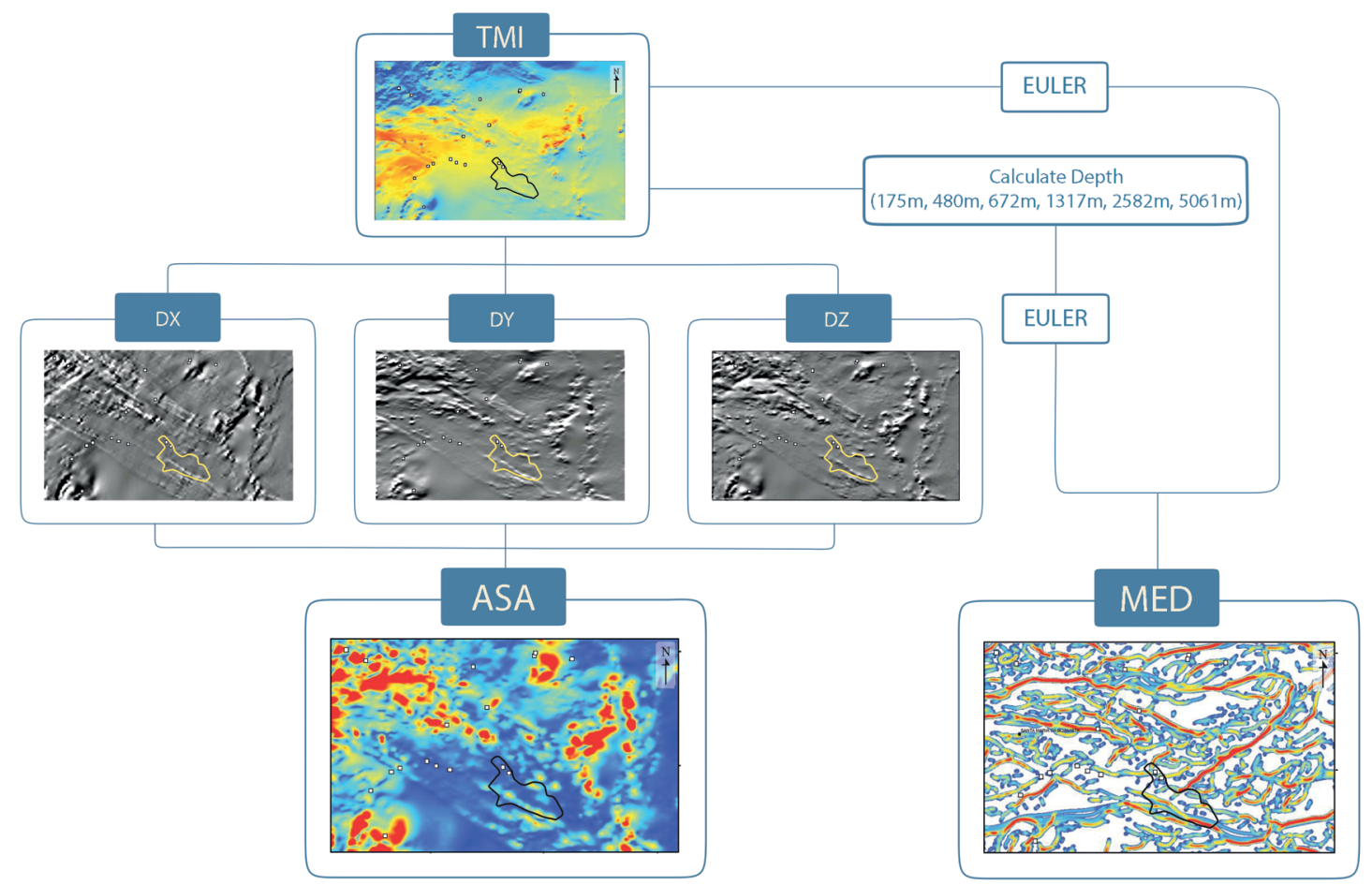

Figure 7. Flowchart of operations illustrating the processing of magnetometric data and the transformations of linear relations in a three component space domain including het anomalous magnetic field (CMA), vertical and horizontal derivatives DZ, DX and DY, and the analytical signal amplitude (ASA). MED is a process of highlight edges in potential field data (Hornby et al. 1999, Archibald et al. 1999). 


\section{Stream sediment and soil geochemistry data}

Principal component analysis was applied to seven multi-element associations ( $\mathrm{Cu}, \mathrm{Ni}, \mathrm{Fe}, \mathrm{P}, \mathrm{La}, \mathrm{Cr}$ and $\mathrm{Zn}$ ) that characterize the known copper occurrences in the Riacho do Pontal prospect. (The Riacho Seco copper project is situated on the NW worm structure parallel to RSSZ in Figure 8). Analyzing the geostatistical behavior of the stream sediment geochemical data according to the matrix of self-vectors of Table 2, it is verified that $\mathrm{Cu}, \mathrm{Ni}, \mathrm{Fe}$ and $\mathrm{La}$ show anomalies from the principal component (PC) 6 and have spatial associations with known copper-gold occurrences (Tab. 1). The sixth principal component (PC6) has high positive loadings for $\mathrm{Cu}, \mathrm{Ni}, \mathrm{Fe}$, and $\mathrm{La}$. This multi-element geochemical map was used to validate the results of the predictive mineral potential of the Riacho do Pontal prospect (Fig. 9).

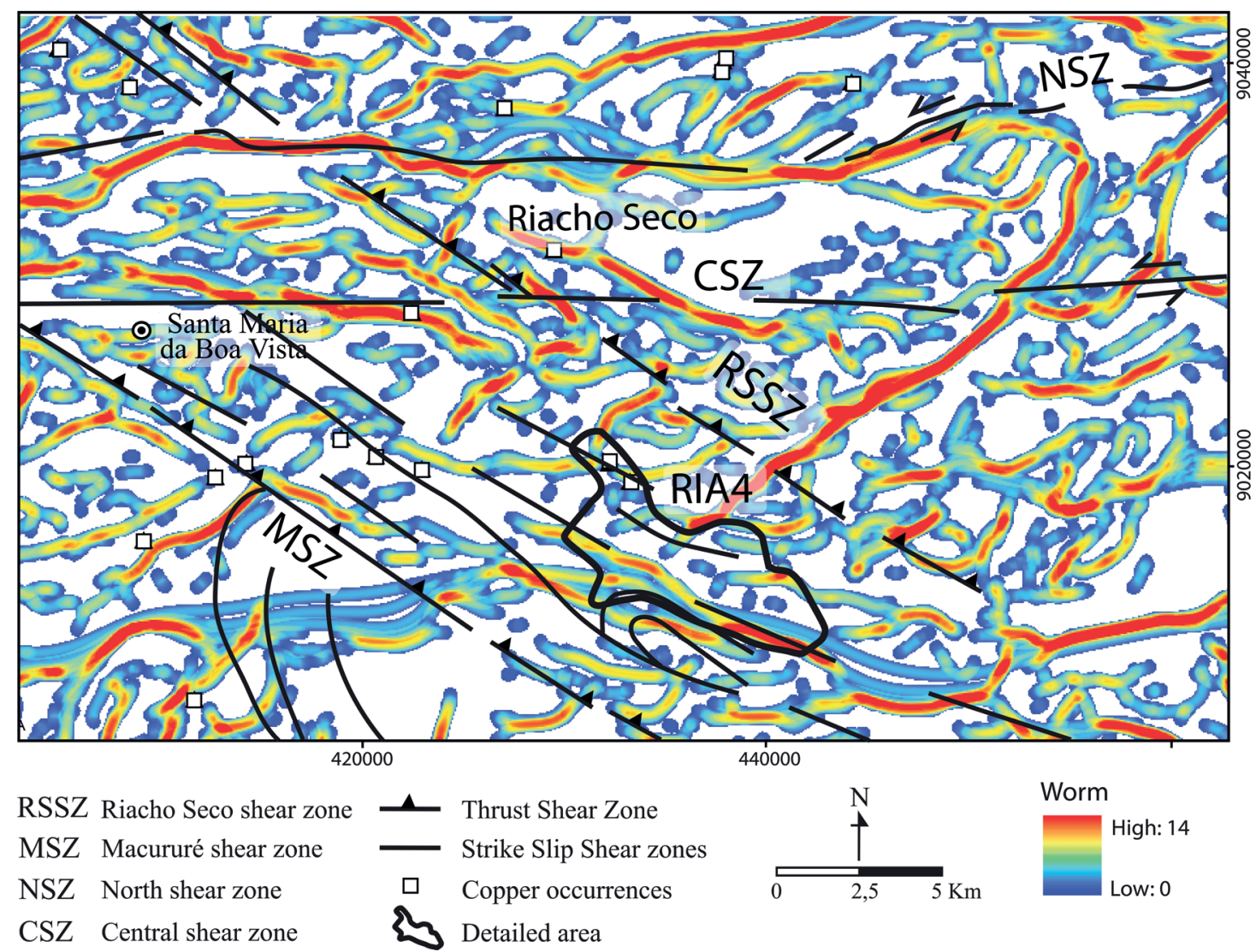

Figure 8. Aeromagnetic worm lineaments with major shear zones and copper occurrences at the Riacho do Pontal prospect. Worming processing highlights the major and secondary structures. The black polygon RIA4 is approached in validation of the potential targets.

Table 2. Principal component analyses of stream sediment data from the Riacho do Pontal prospect.

\begin{tabular}{c|c|c|c|c|c|c|c}
\hline $\begin{array}{c}\text { Principal } \\
\text { Components } \\
\text { Eigenvectors }\end{array}$ & $\mathbf{C u}$ & $\mathbf{N i}$ & $\mathbf{F e}$ & $\mathbf{P}$ & $\mathbf{L a}$ & $\mathbf{C r}$ & $\mathbf{Z n}$ \\
\hline 1 & 0,1916204 & 0,2054073 & 0,1578991 & 0,33218070 & $-0,2501926$ & 0,8951185 & $-0,01005916$ \\
\hline 2 & 0,2473167 & 0,03362516 & 0,2337775 & 0,43689220 & $-0,7604466$ & $-0,4169447$ & 0,02467909 \\
\hline 3 & 0,0409507 & 0,02415018 & 0,0407080 & $-0,0800833$ & 0,319028 & 0,157858 & 0,99849340 \\
\hline 4 & 0,9917154 & $-0,8331272$ & $-0,965052$ & 0,1239673 & 0,085005 & $-0,451941$ & $-0,00032030$ \\
\hline 5 & 0,07891539 & 0,99940824 & $-0,0541230$ & $-0,05125238$ & $-0,0015744$ & 0,003615 & $-0,09393550$ \\
\hline 6 & 0,9566740 & 0,2465354 & 0,424739 & $-0,35370430$ & 0,893393 & $-0,099972$ & $-0,04368640$ \\
\hline 7 & 0,1118552 & 0,5189384 & 0,2266562 & 0,77555328 & 0,0591650 & $-0,1566430$ & $-0,01977967$ \\
\hline
\end{tabular}


The soil sampling at the RIA4 target was projected along profiles oriented sub-perpendicular to the main NW-SE structural/geological trend. The soil geochemical results from the main trend include up to $613 \mathrm{ppm} \mathrm{Cu}, 23 \mathrm{ppb} \mathrm{Au}$, $162 \mathrm{ppm} \mathrm{Zn,} 547$ ppm Ni, 8.94\% Fe and 1.945 ppm Cr (Shriver 2009). The northern and central-northern portions of the area show a positive correlation between $\mathrm{Cu}$ and $\mathrm{Au}$, with anomalous values of $\mathrm{Cu}$. A contour map of the $\mathrm{Cu}$ concentrations shows a cluster of anomalous samples near the gossanic outcrops.

\section{DATA INTEGRATION AND PROSPECTIVITY MAP}

One of the most important decision-making in mineral exploration is the selection of prospects in a given geological environment. Conceptual mineral exploration models based on geology are currently less commonly used than those based on geophysical and geochemical data. Thus, extensive geological knowledge of the exploration model combined with the predictability of integrating multi-source data can increase the exploration success rate. This success rate is closely related to management, and continuous improvement of the database will allow the exploratory model to evolve. Persistence and agility in making "stop and go" decisions are critical for high-potential projects to advance. The approach used in this paper is the knowledge-driven models for data integration and target selection (Bonham-Carter 1994, Ford \& Hart 2013).

Knowledge-based prospectivity mapping was performed by extracting the spatial relationships from exploration datasets based on an exploration model, quantifying and integrating them using mathematical operators chosen by the user. The lower potential areas that do not show evidence of mineralization are assigned very low potentials that are close to, but not exactly, zero. The mathematical operators, fuzzy algebraic product, fuzzy algebraic sum and fuzzy gamma are commonly used in fuzzy data integration (Bonham-Carter 1994, Ford \& Hart 2013, Porwal et al. 2003, Silva et al. 2000).

\section{Application of a fuzzy model to the study area}

The parameters were integrated into a prospectivity map using the fuzzy-logic method first developed by Bonham-Carter (1994). In the fuzzy theory, the members of a fuzzy set are expressed on a continuous scale from 0 to 1 . Values were selected to reflect the degree of membership of a database that has been analyzed based on expert judgment. The various classes of layers of a set of maps can be expressed in terms of fuzzy memberships of different sets and can be stored as an attribute table of a map (Bonham-Carter 1994).

The spatial association between the copper occurrences and structural features can be analyzed using fuzzy logic

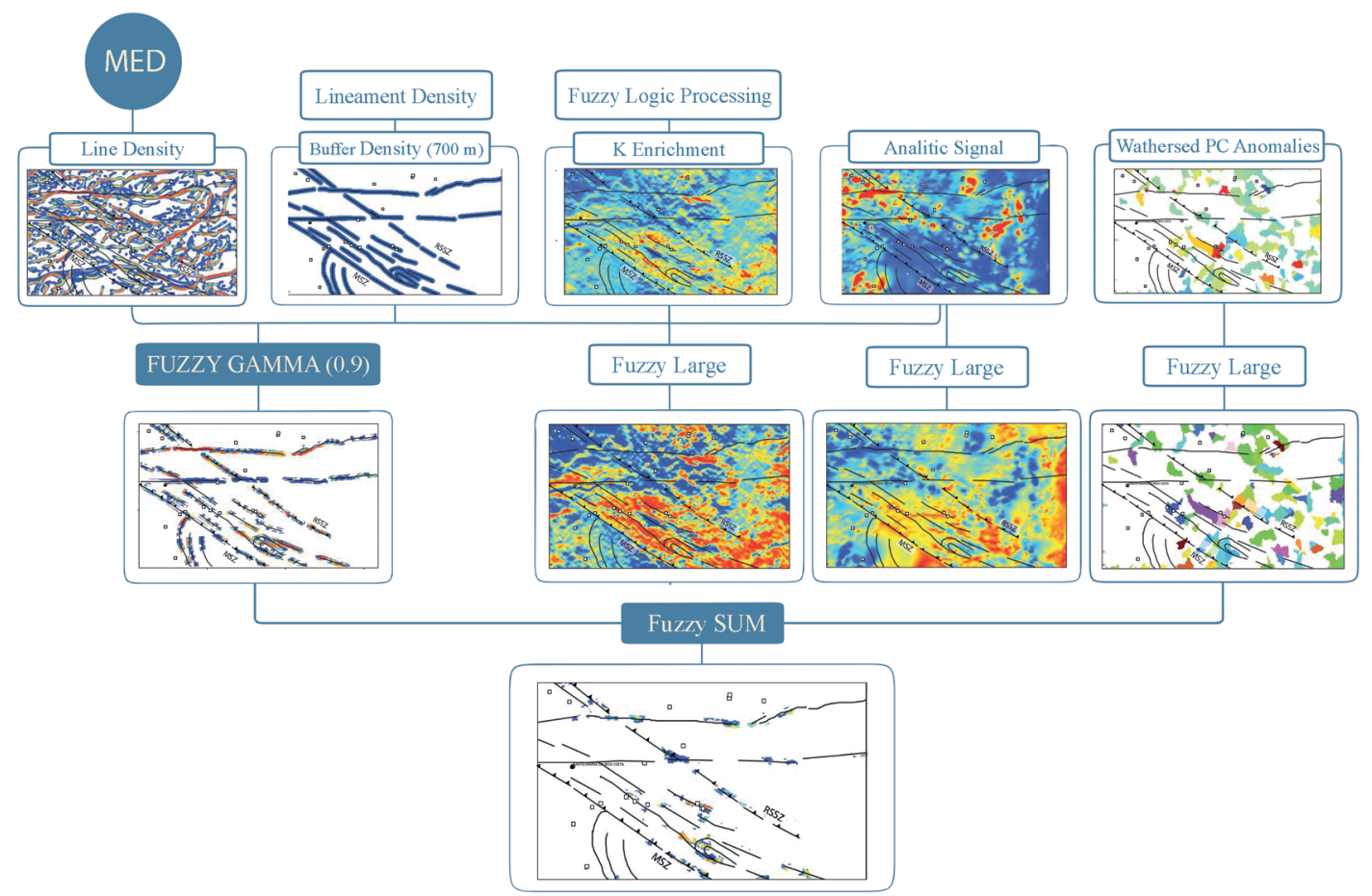

Figure 9. General flow chart of fuzzy data integration modeling using sets of geological, geochemical, structural, magnetic and anomalous potassium maps to select favorable targets for copper deposits. 
to determine whether potential IOCG targets are in connection with geologic structures. The geochemical, structural, magnetic and potassium anomalous maps, after being fuzzified, were combined using fuzzy operators, in order to generate the final model. Frequently used operators are: "Fuzzy-AND," "Fuzzy-OR," "Fuzzy-Soma," Fuzzy-Product" and "Fuzzy-Gamma" (Bonhan-Carter 1994, Carranza \& Hale 2001, Lee 2007).

The structural prediction map integrated a high density of worm features (density of linear features in the neighborhood of each output raster cell) and buffer $(200 \mathrm{~m})$ around mapped linear features. A fuzzy gamma operator of 0.9 was used to combine different maps in order to highlight the potential connectivity between the deep and shallow structures. Such structures have the potential to represent preferential conduits for hydrothermal fluid circulation. The geochemical PC6 prediction map is represented by $\mathrm{Cu}, \mathrm{Fe}, \mathrm{Ni}$ and $\mathrm{La}$ catchment basin anomalous maps.

The geophysical prediction map selected areas with magnetic low signature looking for copper occurrences related to hematite zones along fault zones. Aiming to map areas with potassic hydrothermal alterations, the processing of anomalous potassium was used (Ostrovskiy 1975, Pires 1985). The operator fuzzy sum was performed to integrate the geochemical, structural, magnetic and hydrothermal data. The final predictor map is shown in Figure 9.

The data integration using fuzzy operators was described by Raines et al. (2000) and Nykänen et al. (2008). The Arc-SDM ArcToolbox can be downloaded http://www.ige.unicamp.br/ sdm (Sawatzky et al. 2004). The detailed prospective favorability maps of the area are shown in Figures 10 and 11.
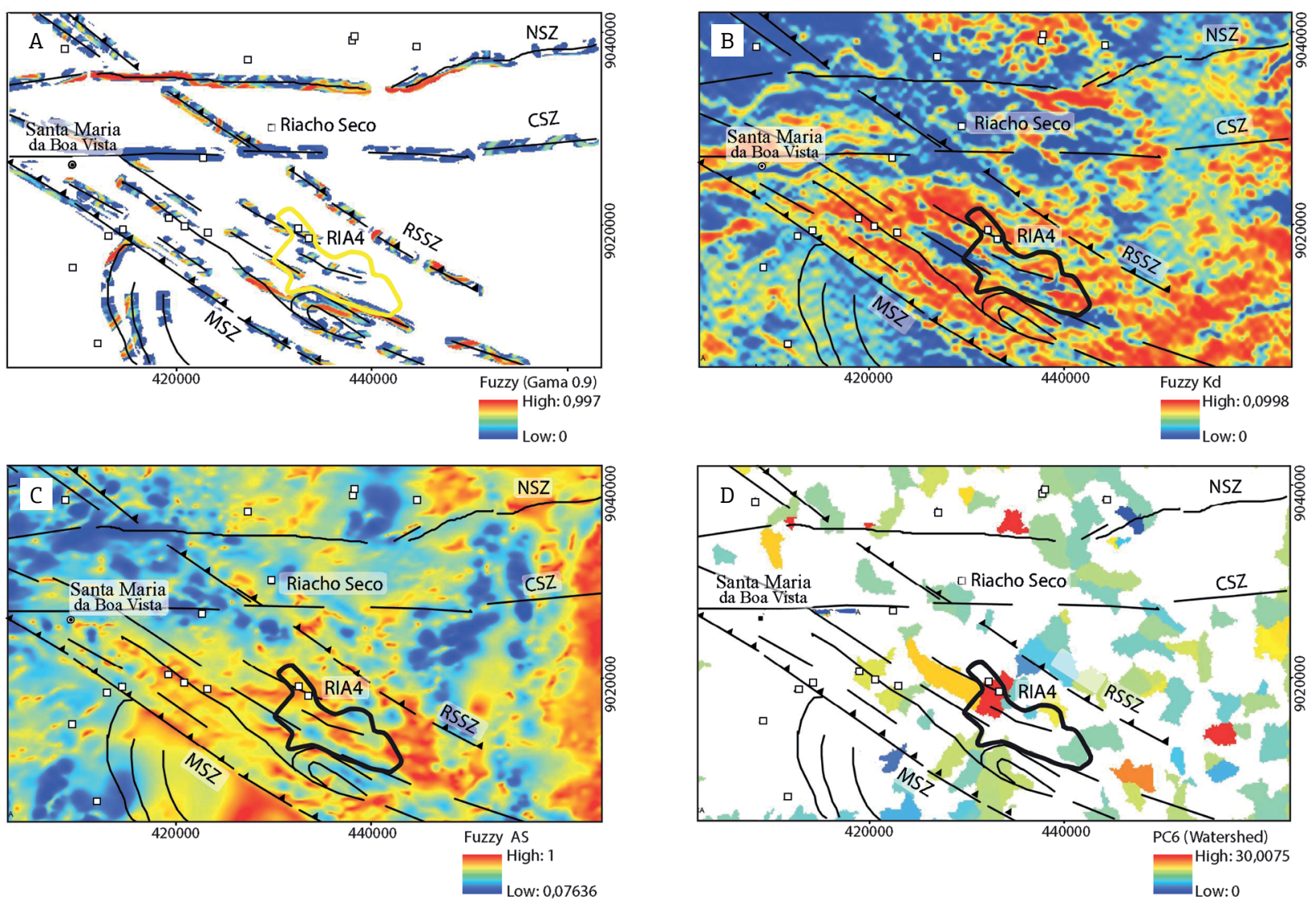

\begin{tabular}{|c|c|c|c|}
\hline RSSZ & Riacho Seco shear zone & 1 & Thrust Shear Zone \\
\hline MSZ & Macururé shear zone & & Major Shear zones \\
\hline CSZ & Central shear zone & & Copper ocurrences \\
\hline NSZ & North shear zone & & Detailed area \\
\hline
\end{tabular}

Figure 10. The figure shows a set of intermediate layer maps used in fuzzy data integration modeling reclassified using the fuzzy membership tools: (A) the relevant intersecting structures; (B) high anomalous potassium values; (C) high analytical signal amplitude values; (D) high positive loadings for $\mathrm{Cu}, \mathrm{Ni}, \mathrm{Fe}$, and $\mathrm{La}$ in the PC6 stream sediment. The black polygon is described in the second part of this paper. 
In the final favorability model of Figure 11 , approximately $10 \%$ of the zones with high potential were identified to host copper mineralization. In particular, special attention should be given to the high score areas in the fuzzy classification, such as the area located between the shear zones RSSZ and MSZ (including target RIA4) and the targets along the NSZ and CSZ.

\section{Validation and assessment of the best targets using a drilling program}

Validation of the potential targets of economic interest represents an important aspect of prospectivity mapping analysis. In this study, the RIA4 target is one of the best potential prospects identified by the regional approach. RIA4 target was selected to validate the exploration model. Figure 12 shows the flow chart for the fuzzy modeling at the scale of RIA4. As for regional scale modeling, different components (structural, soil geochemistry, magnetic, and hydrothermal maps) were selected for data integration and were gridded to RIA4 prospect area. Different from the regional scale modeling, the soil geochemistry, instead of stream sediment geochemistry, was used as the geochemical component.

The prospective maps were integrated using fuzzy AND operator to generate the integrated fuzzy favorability map for IOCG mineralization in the RIA4 target. The potential areas for host copper mineralization at the RIA4 target are shown in the fuzzy favorability map of Figure 13. The medium- and/or high-priority fuzzy areas account for over $22 \%$ of the study area. From the exploration point of view only the north central portion of the area was partially tested by exploratory drilling.

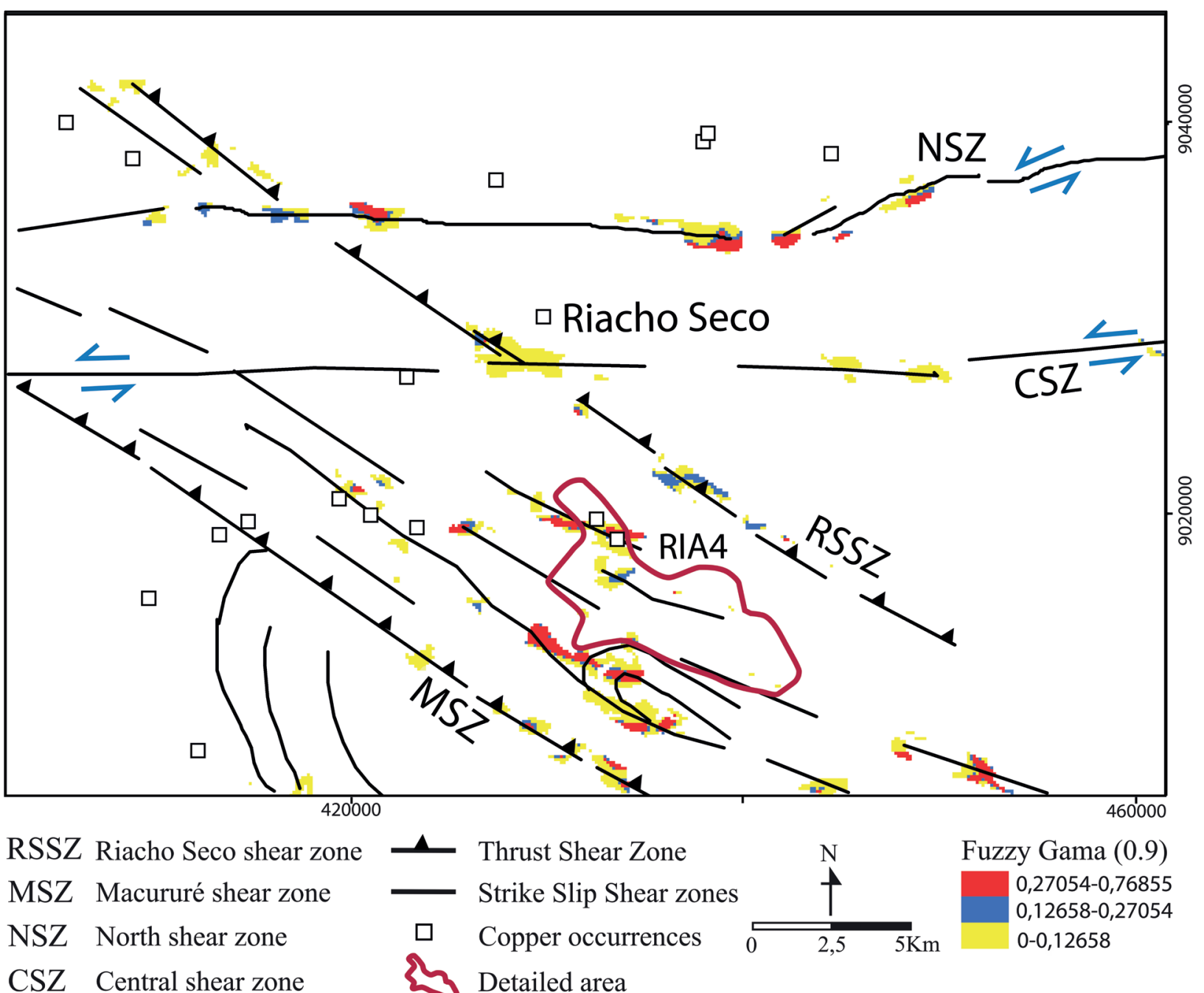

Figure 11. Final classified fuzzy favorability map showing higher-potential areas. The central portion of the area was selected for more detailed exploration activities. The red polygon is approached in validation of the potential targets. 
Two drill holes were located in a high-priority area of the fuzzy favorability map (Fig. 13). Geologically the two drill cores were obtained at the site where malachite is hosted in sheared hematite-biotite-rich rocks. RIA4-DH00001 crosscut the ore zone, which is characterized by pyrite-chalcopyrite-bornite with a $32-\mathrm{m}$ thick zone of $1.15 \% \mathrm{Cu}$. The geochemical results from drill hole RIA4-DH00001 show high values for $\mathrm{Au}$ (243 ppb), Ni (1,675 ppm), Cr (4,020 ppm) and $\mathrm{Zn}$ (390 ppm; Shriver 2009).

Drill hole RIA4-DH00002 intersected banded leucogneiss with silicified zones and several biotite- and amphibole-rich intervals, some of which contained trace chalcopyrite and pyrite. This low-grade mineralization area is interpreted as a zone of trans-tensional deformation (Fig. 14). Drill hole RIA4-DH003 was drilled $1.3 \mathrm{~km}$ southeast of RIA4-DH001. The hole was positioned on the edge of the high-priority anomaly, crosscutting intense biotite-hematite hydrothermal zones with discontinuous mineralized intervals with low grade copper (0.2 wt\%). Drill hole RIA4-DH00004 was drilled $2.5 \mathrm{~km}$ southeast of RIA4-DH0001 in an area with malachite occurrences and intersected biotitic leucogneiss,

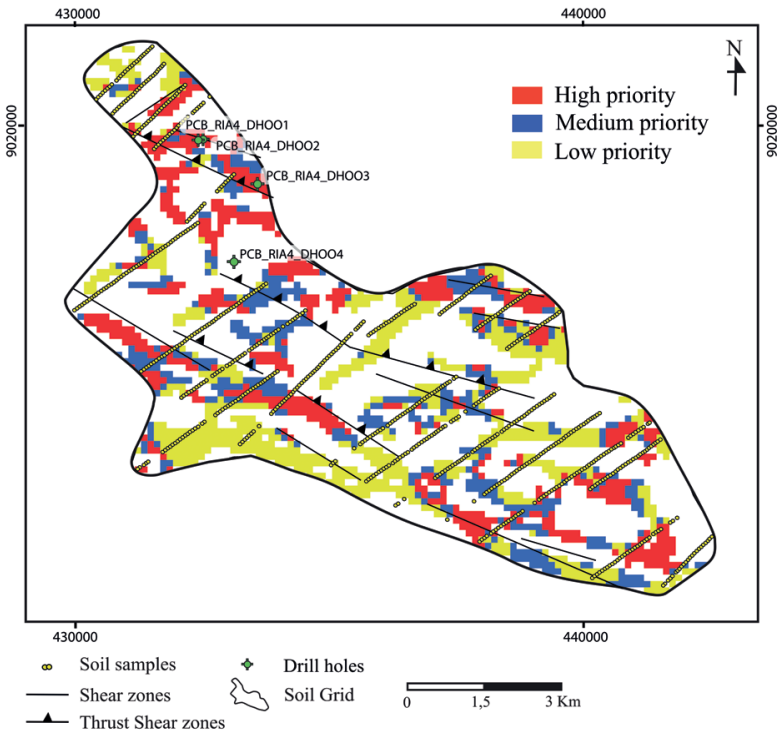

Figure 13. Fuzzy favorability map showing areas of medium and/or high priority that have greater potential to find copper mineralization at the RIA-4 target. Four drill holes were obtained to validate the exploration favorability model.

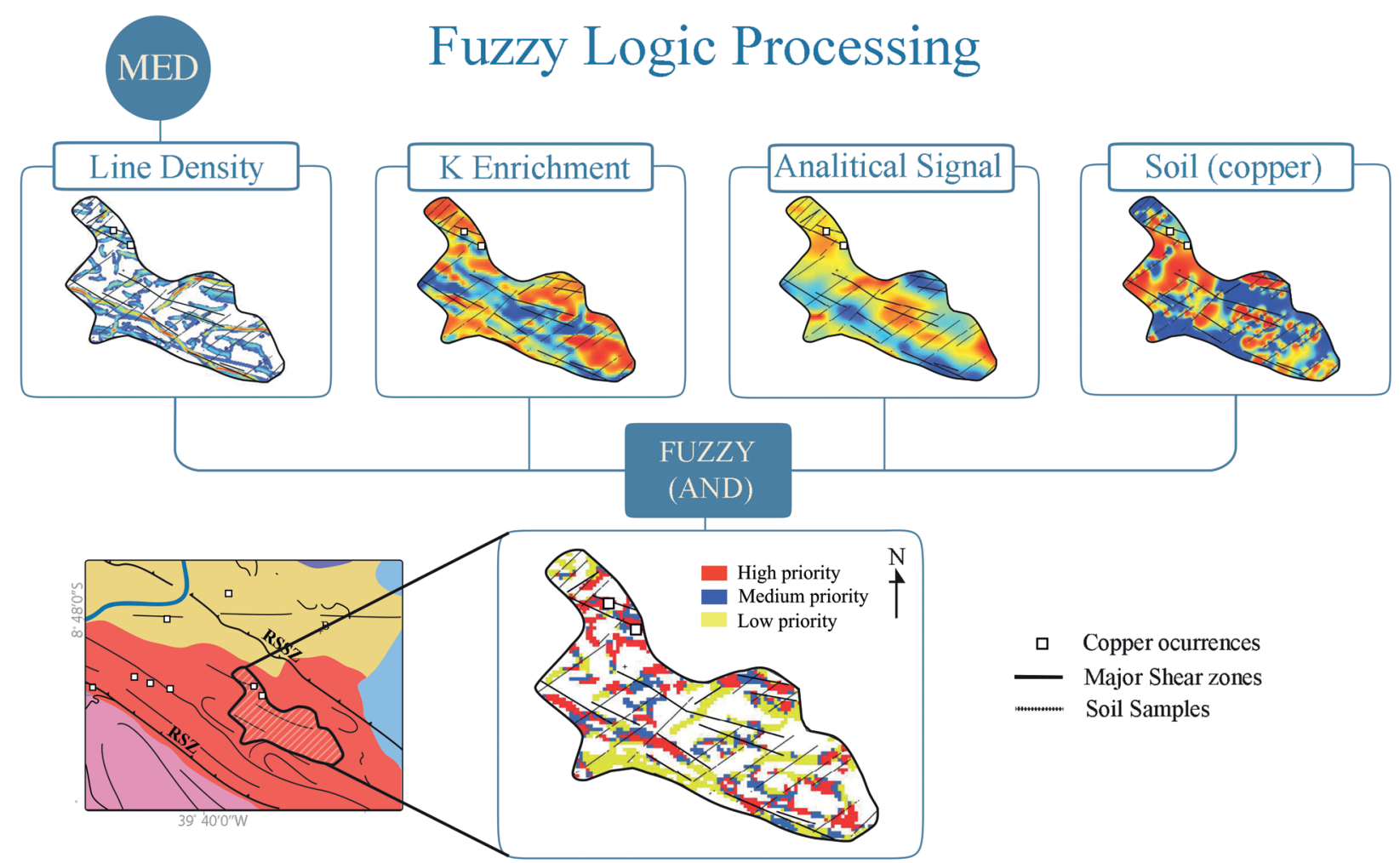

Figure 12. Maps of the fuzzy set of evidence layers. Structure, K enrichment, analytical signal and soil geochemistry were assigned using fuzzy logic weight and the fuzzy logic AND operator. The medium- and/or high-priority areas account for over $22 \%$ of the study area. 
with few and discontinuous garnet-biotite rich intervals and a very low grade of copper. RIA4-DH00004 was located in low-potential areas, as illustrated on the fuzzy favorability map (Fig. 14). The results obtained in the drill holes reported above validate the exploration used in this work. From an exploratory point of view, additional probing is recommended in areas of high potentiality in the fuzzy favorability map. A geological cross section showing drill holes PCBRIA4-DH-01 and DH-02 in the recognized mineralized zone of the Riacho do Pontal prospect is illustrated in Figure 14.

Finally, Figure 14 provides an overview of the data integration, including the outcrop mapping, drilling, model validation, features of the ore zone and the style of mineralization. In the fuzzy analysis of the Riacho do Pontal Belt, the moderately and highly score fuzzy favorable. The high priority targets should be investigated by additional exploration activities.

\section{CONCLUSIONS}

This study used a knowledge-driven fuzzy method to produce a prospectivity map of the area of the Riacho do
Pontal prospect. A comparative evaluation of the results was performed using drill holes in the study area. The results indicate that the fuzzy method can be used to prioritize a prospect area. The proposed method can be applied as a reliable knowledge-based tool for prospective areas of the Riacho do Pontal Belt.

Regional and district-scale fuzzy models were implemented using prediction maps by processing the following exploration datasets: structure density (lineaments and worms), soil and stream sediment geochemistry data, and airborne magnetic and gamma ray data.

The fuzzy analysis that was used to assess the Riacho do Pontal Belt at the regional scale indicated that moderately and highly favorable areas have the potential to host IOCG deposits. The modeling was validated with a drilling exploration program for the target RIA4. Drill hole RIA4-DH001 intersected a 32-m thick mineralized zone that contained $1.15 \% \mathrm{Cu}$.

Finally, in terms of metal endowment, systematic geological, geochemical and geophysical surveys should be conducted on belts that surround the São Francisco Craton as potential tectonic settings for IOCG deposits.

\section{Riacho do Pontal Validadion Model} Overview of the Prospect

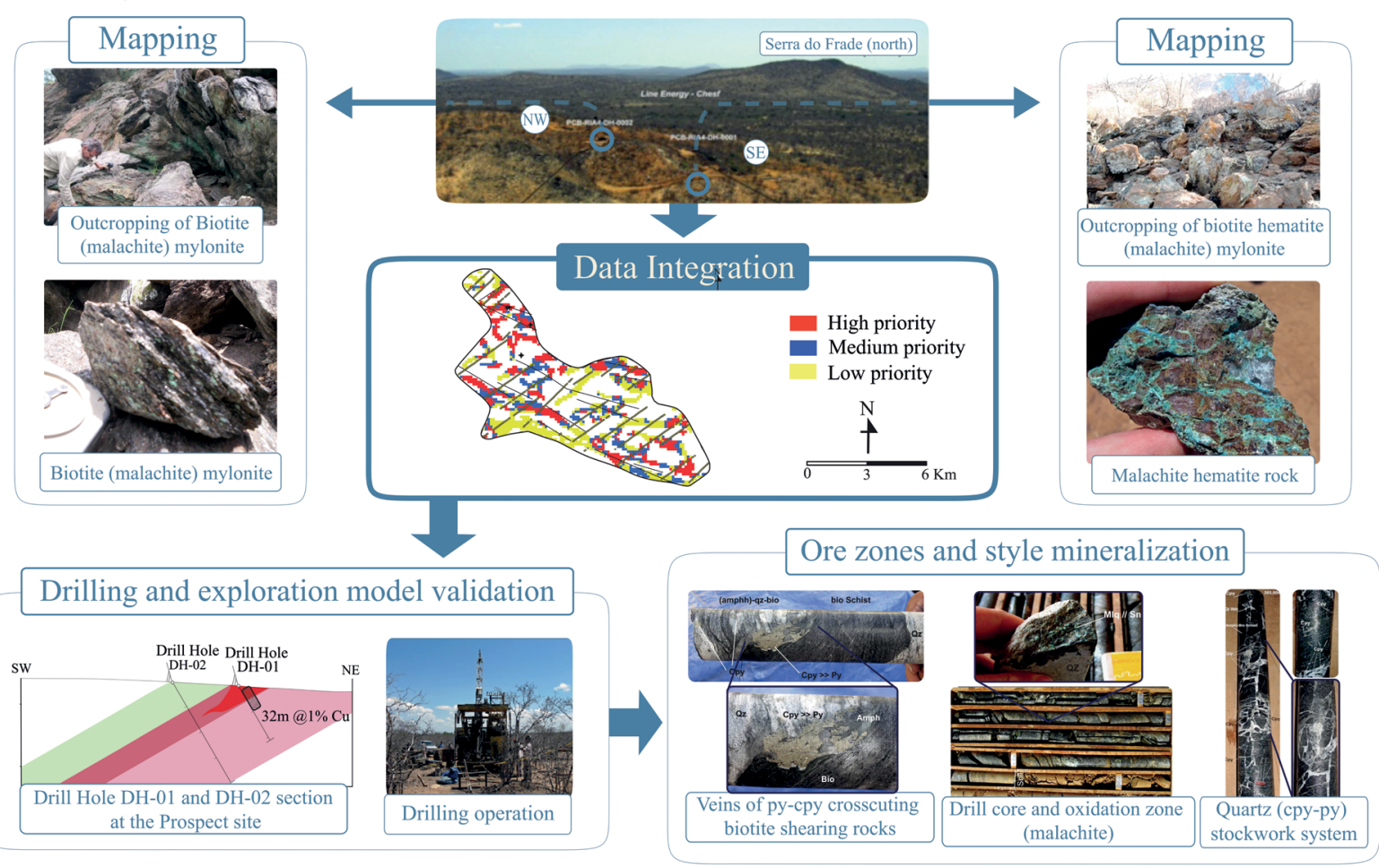

Figure 14. Overview of data integration of the Riacho do Pontal project showing outcrop mapping, drilling, model validation, features of the ore zone and mineralization style. High-priority targets should be investigated by additional exploration activities. 


\section{ACKNOWLEDGMENTS}

The authors gratefully acknowledge Vale S. A. for their support of this study. We would like to thank Fernando Greco, F. Matos and the Vale exploration team for all the extensive discussions. A.M. Silva gratefully acknowledges the National
Council for Scientific and Technological Development (CNPq) for the research grant (307177/2014-9). We would also like to thank Raiza Toledo and Victoria Basileu for their special support in developing the figures, and Pascal Philippot for his constructive comments on different versions of the manuscript.

\section{REFERENCES}

Alkmim F.F., Brito Neves B.B., Castro Alves J.A. 1993. Arcabouço tectônico do Cráton São Francisco: uma revisão. In: Domingues J.M.L., Misi (Eds.), O Cráton do São Francisco. Salvador, SBG/SGM/CNPq, p. 45-62.

Almeida F.F.M., Hasui Y., Brito Neves B.B. 1976. The Upper Precambrian of South América. Boletim IG, São Paulo, 7:45-80. https://doi.org/10.11606/issn.2316-8978.v7i0p45-80

Archibald N., Gow P., Boschetti F. 1999. Multiscale edge analysis of potential field data. Exploration Geophysics, 30:38-44. https://doi. org/10.1071/EG999038

Bonham-Carter G.F. 1994. Geographic information systems for Geoscientists: Modelling with GIS. Oxford, Pergamum, 398 p.

Brito-Neves B.B. 1975. Regionalização geotectônica do Pré-cambriano nordestino. Doctoring thesis, Instituto de Geociências, Universidade de São Paulo, São Paulo, 198 p.

Brito-Neves B.B. 1983. O mapa geológico do nordeste Oriental do Brasil: escala 1:1.000.000. Full Professor Thesis, Instituto de Geociências, Universidade de São Paulo, São Paulo, 177 p.

Brito-Neves B.B., Santos E.J., Van Schmus W.R. 2000. Tectonic history of the Borborema province. In: Cordani U.G., Milani E.J., Thomaz Filho A., Campos D.A. (eds.), Tectonic Evolution of the South America. Tectonic Evolution of the South America. Rio de Janeiro, 31 International Geological Congress, 2000, p. 151-182

Brito-Neves B.B., Van Schmus W.R., Kozuch M., Santos E.J. dos, Petronilho L. 2005. A Zona Tectônica Teixeira Terra NovaZTTTN - Fundamentos da Geologia Regional e Isotópica. Geologia USP Série Científica, 5:57-80. https://doi.org/10.5327/ S1519-874X2005000100005

Buarque D.C. 2007. Extração automática de parâmetros físicos de bacias hidrográficas a partir do MNT para utilização em modelos hidrológicos. Available at: <http://professor.ufrgs.br/sites/default/ files/collischonn/files/trabalho_final_diogo.pdf>. Acessed on: January 10, 2017.

Bueno J.F., Oliveira E.P., McNaughton N.J., Laux J.H. 2009. U-Pb dating of granites in the Neoproterozoic Sergipano Belt, NE-Brazil: Implications for the timing and duration of continental collision and extrusion tectonics in the Borborema Province. Gondwana Research, 15:86-97. http://dx.doi.org/10.1016/j.gr.2008.06.003

Carranza E.J.M., Hale M. 1997. A catchment basin approach to the analysis of reconnaissance geochemical-geological data from Albay Province, Philippines. Journal of Geochemical Exploration, 60:157-171. https://doi.org/10.1016/S0375-6742(97)00032-0

Carranza E.J.M., Hale M. 2001. Geologically constrained fuzzy mapping of goldmineralization potential, Baguio district, Philippines. Natural Resources Research, 10(2):125-136. https://doi. org/10.1023/A:1011500826411

Companhia de Pesquisa de Recursos Minerais (CPRM). Projeto Aerogeofísico Pernambuco - Piauí. Relatório Final do Levantamento e
Processamento dos Dados Magnetométricos e Gamaespectométricos. CPRM, 2006. v. 1. 268 p

Delgado L.M., Souza J.D. 1975. Projeto Cobre Curaça. Geologia Econômica do Distrito Cuprífero do Rio Curaça, Bahia, Brasil. Relatório Final. CPRM, 1975. v. I.

Efimov A.V. 1978. Multiplikativnyj pokazatel dlja vydelenija endogennych rud poaerogamma-spektrometriceskim dannym. In: Metody rudnoj geofiziki. Leningrad, Naucno-proizvodstvennoje objedinenie geofizika.

Ford A., Hart C.J.R. 2013. Mineral potential mapping in frontier regions: a Mongoliancase study. Ore Geology Reviews, 51:15-26. http://dx.doi.org/10.1016/j.oregeorev.2012.11.002

Fraguas S. 2012. Evolução da Mina Caraíba, Bahia. In: Simexmin, 2012. Novos casos de sucesso em exploração mineral $e$ desenvolvimento de minas no Brasil. 2012. CD-ROM.

Franklin J.M., Lydon J.W., Sangster D.F. 1981. Volcanic associated massive sulfide deposits. In: Skinner B.J. (ed.), Economic Geology. 75th Anniversary Volume. Denver, Society of Economic Geologists, p. 485-627.

Fuck R.A., Jardim de Sá E.F., Pimentel M.M., Dardenne M.A., PedrosaSoares A.C. 1993. As faixas de dobramentos marginais do Cráton do São Francisco: síntese do conhecimento. In: Dominguez J.M.L Misi A. (eds.), O Cráton do São Francisco. Salvador, SBG/SGM/ CNPq, p. 121-146.

Garcia P.M.P. 2013. Metalogênese dos Depósitos Cupriferos de Caraiba, Surubim, Vermelhos e Sussuarana, Vale do Curaça, Bahia, Brasil. Dissertation, Universidade Federal da Bahia, Salvador, 223 p.

Gomes H.A. 1998. Programa de Levantamentos Geológicos Básicos do Brasil. Serra Talhada, Folha SC.24-Z-C. Mapa geológico, escala 1:250.000. Brasília, CPRM. 1 CD-ROM.

Grainger C.J., Groves D.I., Tallarico F.H.B., Fletcher I.R., 2008 Metallogenesis of the Carajás mineral province, southern Amazon craton, Brazil: varying styles of Archean through Paleoproterozoic to Neoproterozoic base-and precious-metal mineralization. Ore Geology Reviews, 33:451-489. http://ib.adnxs.com/ seg?add $=1 \&$ redir $=$ http\%3A\%2F\%2Fdx.doi.org\%2F10.1016\%2Fj. oregeorev.2006.10.010

Groves D.I., Bierlen F.K., Meinert L.D., Hitzman M.W. 2010. Iron Oxide Copper-Gold (IOCG) deposits through Earth history: implications for origin, lithospheric setting and distribution from other epigenetic iron oxide deposit. Economic Geology, 105:641-656. http://ib.adnxs.com/seg?add=1\&redir=http\%3A\%2F\%2Fdx.doi. org\%2F10.2113\%2Fgsecongeo.105.3.641

Hitzman M.W. 2000. Iron oxide-Cu-Au deposits: what, where, when and why. In: Porter T.M. (ed.), Hydrothermal iron oxide copper-gold and related deposits: a global perspective. Adelaide, Australian Mineral Foundation, p. 9-25. 
Hitzman M.W., Oreskes N., Einaudi M.T. 1992. Geological characteristics and tectonic setting of Proterozoic iron oxide (Cu-U-Au-REE) deposits. Precambrian Research, 58:241-287. http://ib.adnxs.com/seg?add=1\&redir=http\%3A\%2F\%2Fdx.doi. org\%2F10.1016\%2F0301-9268(92)90121-4

Hornby P., Boschetti F., Horowitz F.G. (1999). Analysis of potential field data in the wavelet domain. Geophysical Journal International, 137(1):175-196. https://doi.org/10.1046/j.1365-246x.1999.00788.x

Hühn S.R.B., Justo A.P., Souza Filho C.R., Monteiro LV.S. 2011. Caracterização geológica do prospecto de óxido de ferro-cobre-ouro (IOCG) Aurora, Ceará, Brasil. Revista Brasileira de Geociências, 41(3):525-538.

Hühn S.R.B., Nascimento J.A.S. 1997. São os depósitos cupríferos de Carajás do Tipo Cu-Au-U-ETR? In: Costa M.L., Angélica R.S. (Coords.), Contribuições à Geologia da Amazônia. Belém, FINEP.SBG-NO, p. 143-160.

Hühn S.R.B., Sousa M.J., Souza Filho C.R., Monteiro L.V.S. 2014. Geology of the Riacho do Pontal iron oxide copper-gold (IOCG) prospect, Bahia, Brazil: hydrothermal alteration approached via hierarchical cluster analysis. Brazilian Journal of Geology, 44(2):309-324. http:// dx.doi.org/10.5327/Z2317-4889201400020010

Jardim de Sá E.F. 1994. A Faixa Seridó (Província Borborema, NE do Brasil) e o seu significado geodinâmico na Cadeia Brasiliana/ Pan-Africana. PhD Thesis, Instituto de Geociências, Universidade de Brasília, Brasília, 803 p.

Jardim de Sá E.F., Macedo M.H.F., Fuck R.A. 1992. Terrenos Proterozóicos na Província Borborema e a margem norte do Cráton São Francisco. Revista Brasileira de Geociências, 22:472-480

Juliani C., Monteiro L.V., Fernandes C.M.D. 2016. Potencial mineral: cobre. In: Melfi A.J., Misi A., Campos D.A., Cordani U.G. (Eds.), Recursos Minerais do Brasil: problemas e desafios. p. 134-153.

Lee S. 2007. Application and verification of fuzzy algebraic operators to landslide susceptibility mapping. Environmental Geology, 52(4):615-623. http://dx.doi.org/10.1007/s00254-006-0491-y

Li J.Y., He G.Q., Xu X., Li H.Q., Sun G.H., Yang T.N., Gao L.M., Zhu Z.X. 2006. Crustal tectonic frame work of northern Xinjiang and adjacent regions and its formation. Acta Geologica Sinica, 80:148-168.

Lindenmayer Z.G. 1981. Evolução geológica do Vale do Curaça e dos corpos máfico-ultramáficos mineralizados a cobre. Dissertation, Universidade Federal da Bahia, Salvador, 140 p.

Lindenmayer Z.G. 2003. Depósito de Cu-Au do Salobo,Serra dos Carajás: Uma revisão. In: Ronchi L.H., Althoff F.J. (Eds.), Caracterização e modelamento de depósitos minerais. São Leopoldo, Editora Unisinos, p. 69-98.

Maas M.V.R., Oliveira C.G., Pires A.C.B., Moraes R.A.V. 2003. Aplicação da geofísica aérea na exploração mineral e mapeamento geológico do setor sudoeste do Cinturão Cuprífero Orós-Jaguaribe. Revista Brasileira de Geociências, 33(3):279-288.

Machado M.A. 2006. Caracterização Descritiva e Genética de Ocorrências Cupro-Hematíticas no Setor Sudoeste do Sistema Orós-Jaguaribe Província Borborema. Dissertation, Universidade de Brasília, Brasília, 100 p.

Monteiro L.V.S., Xavier R.P., Carvalho E.R., Hitzman M.W., Johnson C.A., Souza Filho C.R., Torresi I. 2008. Spatial and temporal zoning of hydrothermal alteration and mineralization in the Sossego iron oxide-copper-gold deposit, Carajás Mineral Province, Brazil: Paragenesis and stable isotope constraints. Mineralium Deposita, 43:129-159. https://doi.org/10.1007/s00126-006-0121-3

Naghibian M.N. (1972). The analytic signal of two-dimensional magnetic bodies with polygonal cross-section: its properties and use for automated anomaly interpretation. Geophysics, 37:507-517. https://doi.org/10.1190/1.1440276
Nykänen V., Groves D.I., Ojala V.J., Eilu P., Gardoll S.J. 2008. Reconnaissance-scale conceptual fuzzy-logic prospectivity modelling for iron oxidecopper - gold deposits in the northern Fennoscandian Shield, Finland. Australian Journal of Earth Sciences, 55(1):25-38. https://doi.org/10.1080/08120090701581372

Oliveira E.P., Tarney J. 1995. Genesis of the copper-rich Caraiba norite - Hypersthenite Complex. Brasil. Mineralium Deposita, 30:351-373. https://doi.org/10.1007/BF00202279

Oliveira E.P., Toteu S.F., Araújo M.N.C., Carvalho M.J., Nascimento R.S., Bueno J.F., McNaughton N., Basilici G. 2006. Geologic correlation between the Neoproterozoic Sergipano Belt (NE Brazil) and the Yaoundé Belt (Cameroon Africa). Journal of African Earth Sciences, 44:470-778. https://doi.org/10.1016/j.jafrearsci.2005.11.014

Oliveira R.G. 2008. Arcabouço Geofísico, Isostasia e Causas do Magmatismo Cenozóico da Província Borborema e de sua margem Continental (Nordeste do Brasil). Thesis, Universidade Federal do Rio Grande do Norte, Natal, 411 p.

Oliveira R.G., Medeiros V.C. 2000. Contrastes geofísicos e heterogeneidade crustal do terreno Pernambuco-Alagoas, Província Borborema, NE Brasil. In: Simpósio de Geologia do Nordeste, 17., Recife. Resumos, p. 176. SBG-Núcleo Nordeste.

Ostrovskiy E.A. 1975. Antagonism of radioactive elements in wallrock alteration fields and its use in aerogamma spectrometric prospecting. International Geology Review, 17:461-468. https://doi. org/10.1080/00206817509471687

Pires A.C.B. 1985. Identificação geofísica de áreas de alteração hidrotermal, Crixás-Guarinos, Goiás. Revista Brasileira de Geociências, 25:61-68

Pollard P.J. 2001. Sodic-(calcic) alteration in Fe-oxide-Cu-Au districts: an origin via unmixing of magmatic $\mathrm{H} 2 \mathrm{O}-\mathrm{CO} 2-\mathrm{NaCl}$ + CaCl2-KCl fluids. Mineralium Deposita, 36:93-100. http:// ib.adnxs.com/seg?add=1\&redir=http $\% 3 \mathrm{~A} \% 2 \mathrm{~F} \% 2 \mathrm{Fdx}$.doi. org\%2F10.1007\%2Fs001260050289

Porwal A., Carranza E.J.M., Hale M. 2003. Knowledge-driven and data-driven fuzzy models for predictive mineral potential mapping. Natural Resources Research, 12(1):1-25. https://doi. org/10.1023/A:1022693220894

Raines G.L., Bonham-Carter G.F., Kemp L.D. 2000. Weights of evidence: an arcview extension for predictive probabilistic modeling: ArcUser. ESRI.

Roest W.R., Verhoef J., Pilkington M. 1992. Magnetic interpretation using the 3-D analytic signal. Geophysics, 57(1):116-125. https://doi. org/10.1190/1.1443174

Santos E.J. 1996. Ensaio preliminar sobre terrenos e tectônica acrescionária na Província Borborema. In: Congresso Brasileiro de Geologia, 39., Salvador. Anais. Salvador, SBG, p. 47-50.

Santos E.J, Oliveira R.G., Paiva I.P. 1997. Terrenos do Domínio Transversal da Província Borborema: controles sobre acresção e retrabalhamento crustais ao sul do Lineamento Patos. In: Simpósio de Geologia do Nordeste, 17. Resumo Expandido. p. 11-14.

Saunders D.F., Terry S.A., Thompson C.K. 1987. Test of National Uranium Resource Evaluation gamma-ray spectral data in petroleum reconnaissance. Geophysics, 52(11):1547-1556. https:// doi.org/10.1190/1.1442271

Sawatzky D.L., Raines G.L., Bonham-Carter G.F., Looney C.G. 2004. ARCSDM3.1: ArcMAP extension for spatial data modelling using weights of evidence, logistic regression, fuzzy logic and neural network analysis. Available at: <http://www.ige.unicamp.br/sdm/ArcSDM31/download/ ArcSDM3_1_Documentation.pdf>. Accessed on: March 10, 2016. 
Shriver A.N. 2009. Vale S.A. Internal report. Riacho do Pontal, Bahia: Geochemistry Review. 11 p.

Silva A.M., McCafferty A., Pires A.C., Rodrigues L.C. 2000. Predictive Geophysical Model for Gold mineralization in the Quadrilátero Ferrifero, Brazil: the case of Cuiabá Revista Brasileira Geociências, Brasília, 30(3):539-542.

Tallarico F.H.B., Figueiredo B.R., Groves D.I., Kositicin N., McNaughton N.J., Fletcher I.R., Rego J.L. 2005. Geology and SHRIMP U-Pb geochronology of the Igarapé Bahia deposit, Carajás copper-gold belt, Brazil: an Archean $(2.57 \mathrm{Ga})$ example of iron-oxideCu-Au(U- REE) mineralization. Economic Geology, 100:7-28. https://doi. org/10.2113/100.1.0007

Teixeira J.B.G., Silva M.G. da, Lindenmayer Z.G., D’el-Rey-Silva L.J.H., Vasconcelos P.M., Reis C.H.C., Andrade J.B.F. 2010. Depósitos de cobre do Vale do Rio Curaçá, Bahia. In: Brito R.S.C., Silva M.G., Kuyumjian R.M. (Eds.), Modelos de depósitos de cobre do Brasil e sua resposta ao intemperismo. Brasília, CPRM, $190 \mathrm{p}$.

Vale S.A. 2009. GANFK - Programa Cu-Ni Brasil, Alvo Riacho do Pontal - Ba, Informe Executivo. Relatório interno. Vale S.A., 15 p.
Xavier R.P., Monteiro L.V.S., Souza Filho C.R., Torresi I., Carvalho E.R., Dreher A.M., Wiedenbeck M., Trumbull R.B., Pestilho A.L.S., Moreto C.P.N. 2010. The Iron Oxide Copper-Gold Deposits of the Carajas Mineral Province, Brazil: an Updated and Critical Review. In: Porter T.M. (Ed.), Hydrothermal Iron Oxide Copper-Gold and Related Deposits: A Global Perspective. Adelaide, PGC Publishing, v.3, p. 285-306.

Xavier R.P., Wiedenbeck M., Trunbull R.B., Dreher A.M., Monteiro L.V.S., Rhede D., Araújo C.E.G., Torresi I. 2008. Tourmaline B-isotopes fingerprint marine evaporates as the source of highsalinity ore fluids in iron oxide-copper-gold deposits, Carajás Mineral Province (Brazil). Geology, 36:743-746.

Williams P.J 2010. "Magnetite-Group” IOCGs with Special Reference to Cloncurry (NW Queensland) and Northern Sweden: Settings, Alteration, Deposit Characteristics, Fluid Sources and Their Relationship to Apatite-Rich Iron Ores. Short Course Notes, v. 20, p. 23-38. Canada, Geological Association of Canada.

Williams P.J., Barton M.D., Johnson D.A, Fontboté L., de Haller A., Mark G., Oliver N.H.S., Marschik R. 2005. Iron oxide-copper-gold deposits: Geology, spacetime distribution, and possible modes of origin. In: Hedenquist J.W., Thompson J.F.H., Goldfarb R.J., Richards J.P. (Eds.) Economic Geology, 100th Anniversary Volume. SEG, p. 371-405. 